Vol. 7(11), pp. 271-276, November, 2015

DOI: $10.5897 / J E N E 2015.0538$

Article Number: 6E4E54455715

ISSN 2006-9847

Copyright (C) 2015

Journal of Ecology and the Natural Environment

Author(s) retain the copyright of this article

http://www.academicjournals.org/JENE

\title{
An inventory of plant species found in gravel borrow pit around Gaborone, Botswana
}

\author{
Israel A. Legwaila*, Gaone T. Thebe and Tebogo Selebatso
}

Botswana College of Agriculture, Department of Crop Science and Production, Private Bag 0027, Gaborone, Botswana.

Received 27 August, 2015; Accepted 28 September, 2015

\begin{abstract}
This study sought to establish an inventory of plant species established at three gravel borrow pits around Gaborone, Botswana. At each, plant data were collected from randomly selected $10 \times 10 \mathrm{~m}$ quadrats within and up to $30 \mathrm{~m}$ away from the borrow pits. Species of Acacia were the most numerous in the pits, while more non-woody than woody species were established within the pits. Most woody species within the pits were not found around the pits, and most of the non-woody species within the pits were found around them, with the exception of the Tlokweng pit.
\end{abstract}

Key words: Re-vegetation, reclamation, pioneer species, seed bank, borrow pit, Acacia.

\section{INTRODUCTION}

Quarrying for gravel has a number of negative impact that affect the integrity of the environment including degradation of ecosystems. The removal of vegetation reduces the ecology of a site and exposes it to other environmental factors such as soil erosion that may exacerbate the negative impacts already caused. However, efforts have been made worldwide to reduce these negative impacts through reclamation by recontouring and re-vegetation (Cripps et al., 2004). In both cases, natural succession will occur, re-establishing native vegetation on the sites. This happens through species colonization, spreading, displacement and replacement over time until climax species are established (Davis et al., 1985). These processes happen as the quarry soils change overtime due to weathering and other physical, chemical and biological processes fed by pioneer species, (Legwaila, 2012). Under natural succession, establishment of vegetation on disturbed land is dependent on the availability of a seed bank from vegetation adjacent to a disturbed site. Landform and soil characteristics may also have an impact on establishment of vegetation (Davy, 2008). Landform in disturbed land may experience accelerated erosion and runoff, inhibited infiltration and unfavourable micro climatic conditions, all of which have a negative effect on the natural recovery processes of disturbed land (Whisenant, 2008). Where topsoil has been replaced after decommissioning of a borrow pit, the soil is expected to carry numerous seeds of plant species from the local environment. However, it generally takes longer for environmental impacts to decrease and for desired outcomes to be achieved under natural succession than under technical reclamation and there will always be left over impacts regardless of the type of reclamation interventions (Figure 1). When technical re-vegetation is undertaken, the process may occur more rapidly resulting in more rapid re-vegetation.

Technical re-vegetation however, requires amelioration

${ }^{*}$ Corresponding author. E-mail: ialegwaila@gmail.com.

Author(s) agree that this article remain permanently open access under the terms of the Creative Commons Attribution License 4.0 International License 


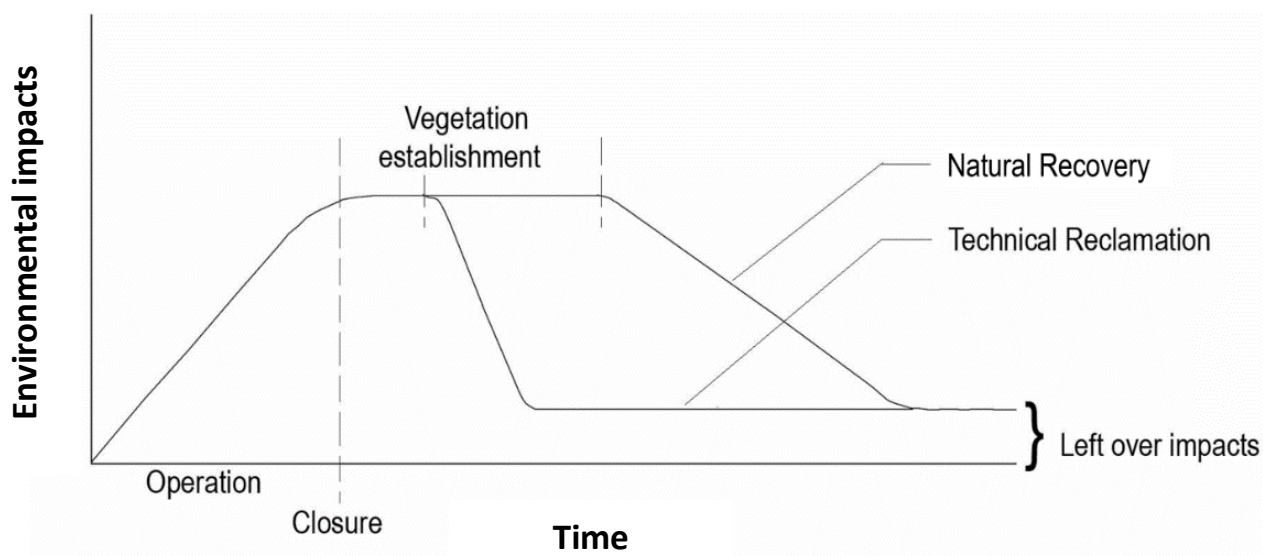

Figure 1. An illustration of the extent of environmental impacts over time after different reclamation interventions (Legwaila, 2012).

Table 1. Geographiccoordinatesof the sites.

\begin{tabular}{|c|c|c|c|}
\hline \multirow{2}{*}{ Corners } & \multicolumn{3}{|c|}{ Place } \\
\hline & Bokaa & Tlokweng & Mmokolodi \\
\hline A & $\mathrm{S} 24^{\circ} 26^{\prime} 02 \mathrm{E} 26^{\circ} 02^{\prime} 49.5$ & $\mathrm{~S}^{\prime} 4^{\circ} 40^{\prime} 20.52 \mathrm{E} 26^{\circ} 02^{\prime} 14.8648$ & $\mathrm{~S}^{\prime} 4^{\circ} 28^{\prime} 09.0 \mathrm{E} 26^{\circ} 58^{\prime} 14.0$ \\
\hline B & S $24^{\circ} 26^{\prime} 03 \quad$ E $26^{\circ} 02^{\prime} 58.8$ & $\mathrm{~S} 24^{\circ} 40^{\prime} 19.90 \mathrm{E} 26^{\circ} 02^{\prime} 25.7320$ & $\mathrm{~S} 24^{\circ} 28^{\circ} 07.0 \mathrm{E} 26^{\circ} 58^{\prime} 23.0$ \\
\hline C & $S 24^{\circ} 25^{`} 52 \quad \mathrm{E} 26^{\circ} 02 ` 57.7$ & $\mathrm{~S} 24^{\circ} 40^{\prime} 29.39 \mathrm{E} 26^{\circ} 02^{\prime} 24.4906$ & $S 24^{\circ} 28^{\prime} 17.0$ E $26^{\circ} 58^{\prime} 36.0$ \\
\hline D & $\mathrm{E} 26^{\circ} 0215.7$ & $\mathrm{~S} 24^{\circ} 40^{\prime} 29.13 \mathrm{E} 26^{\circ} 02^{\prime} 13.3490$ & S $24^{\circ} 28^{\prime} 25.3$ E $26^{\circ} 58^{\prime} 28.0$ \\
\hline
\end{tabular}

of the quarry soils to support plant life as well as proper choice of plants which can survive the local conditions and provide the functions that are intended for the quarry after reclamation. This requires knowledge and selection of native species that are common to establish in disturbed land and be productive under less than normal conditions of quarry sites to ensure sustainability of the vegetation. It has been found in other studies that at times exotic species establish in decommissioned quarry sites, and has been concluded that they may have been introduced by humans (Davis et al., 2000). It has also been concluded that use of non-native species is "the second most important threat to biodiversity after habitat loss", (Vermeulen and Whitten, 1999).

This study sought to identify and develop an inventory of plant species that established in borrow pits that were quarried for gravel around the city of Gaborone, Botswana.

\section{METHODOLOGY}

\section{Study sites}

This study was conducted at three decommissioned borrow pits around Gaborone. The pits were located in the villages of Bokaa, Mmokolodi and Tlokweng. These borrow pits came about as a result of the high infrastructure construction developments that occurs in the city of Gaborone and the neighbouring areas. The land in these areas was previously used for communal grazing. The borrow pits were selected based on their close proximity to Gaborone. Their coordinates were taken at four corners of the sites (Table 1). The soils around these sites were slightly variable but generally supported a shrub savanna and savanna vegetation structure. The soils around Bokaa and Tlokweng pits were haplic lixisols which are common in the tropics with predominant dry seasons. They form subsequent to leaching of clay. They have very low levels of plant nutrients and are highly erodible. Mmokolodi on the other hand had eutric regosols which are weakly developed soils very common in unstable landforms. They also have low levels of nutrients and nutrient holding capacity.

\section{Experimental design}

Within each borrow pit site, four (4) quadrants of $10 \mathrm{~m}$ by $10 \mathrm{~m}$ were randomly selected. Around each borrow pit, eight quadrants of $10 \mathrm{~m}$ by $10 \mathrm{~m}$ from different sides of the pits were randomly selected to conduct an inventory of plant species around the pits. This procedure was performed to enable comparison of plant species within the borrow pits and those aroundthem.

\section{Collection and identification of plant species}

All plants seen in the quadrats were recorded to species level. For those that could not be reliably identified in the field, specimens were collected for later identification in the herbarium at the Botswana College of Agriculture. The same procedure was 
Table 2. Plant species found within the three borrow pits.

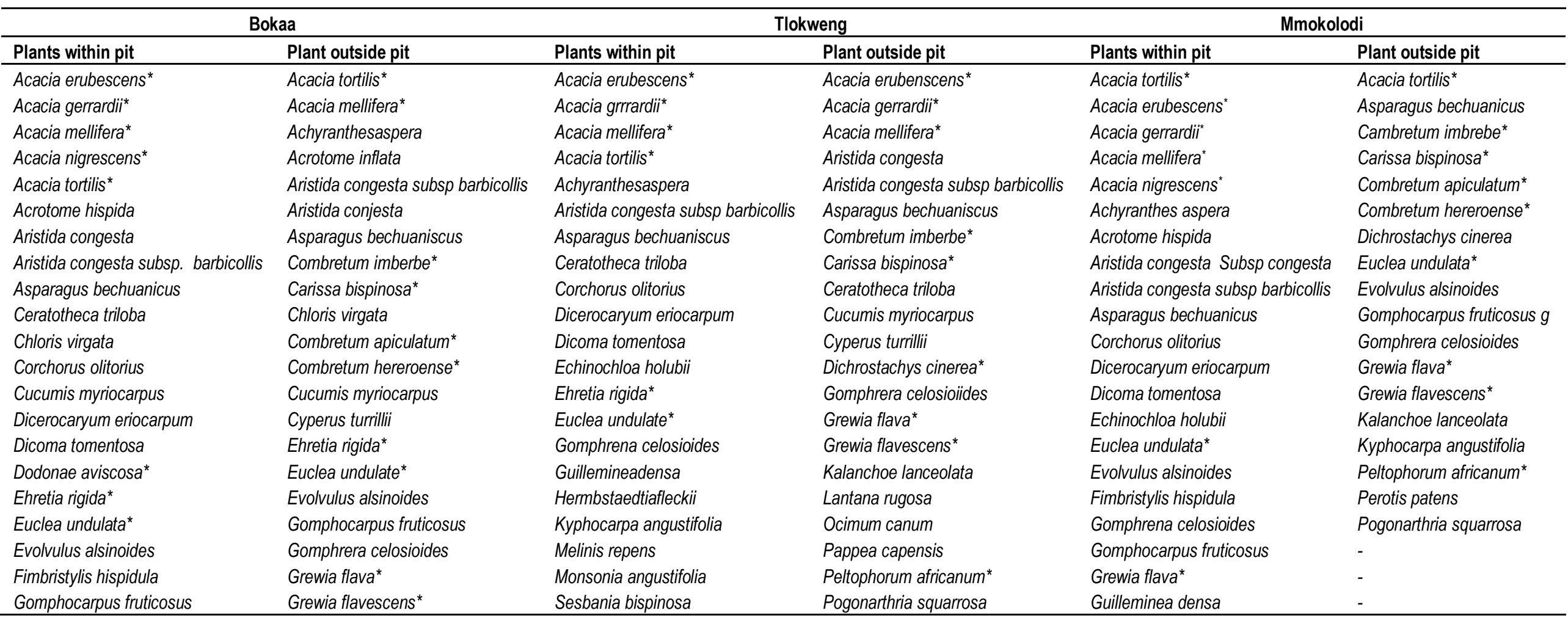

conducted outside the borrow pits from a distance of $30 \mathrm{~m}$ to the edge of the pits.

\section{RESULTS AND DISCUSSION}

Overall there were 44 species ( 11 woody and 33 non-woody) found at all borrow pits (Table 2). The woody species made a total of $25 \%$ of all the species found. The majority of the woody species were Acacia species making $46 \%$ (five different species). All of the other six species contributed $9 \%$ each. A total of 5 woody species, four Acacia species and Euclea undulate were present at each of the pits, (Table 3). The predominance of the Acacia species might be an indication of their greater tolerance to low levels of resources within the pits (Smith and Smith, 2014; Donfack et al., 1995). This enables them to efficiently exploit the little resources in the soil, better than other species. There was also an exotic species (Dodonea viscosa) at Bokaa pit commonly used as an ornamental plant in Botswana. Its existence in the pit could be attributed to the anthropogenic activities that took place at the pit during operation (Davis et al., 2000). Of the 33 non-woody species found at the different pits, $12(36 \%)$ were common to all pits (Table 3 ).

There was a high number of non-woody plants that made the understory made up of grasses and small shrubs. The trees that existed with them might have created conducive micro-climatic and soil conditions, facilitating their growth and establishment (Smith and Smith, 2014; Whisenant, 2008).

It was expected that most plants that established within the borrow pits would either have been from the soil seed bank in the surrounding land or as a result of seed dispersion 
Table 2. Contd.

\begin{tabular}{lllll}
\hline Gomphrena celosioides & Kalanchoe lanceolata & Streptopetalum serattum & Streptopetalum serattum & Hermbstaedtiafleckii \\
Grewia flava* & Kyphocarpa augustifolia & Tricholaena monachne & Tricholaena monachne & Hypertelis bowkeriana \\
Guilleminea densa & Lantana rugosa & Urochloa mosambicensis & Urochloa mosambicensis & Kohautia subverticilla \\
Hermbstaedtiafleckii & Ocimum canum & Ziziphus mucronata* & Zyzypus mucronata* & Kyphocarpa angustifolia \\
Hypertelis bowkeriana & Pappea capensis & - & - & Melinis repens \\
Kohautia subverticillata & Peltophorum africanum* & - & - & Monsonia angustifolia \\
Kyphocarpa angustifolia & Perotis patens & - & - & Pogonarthria squarrosa \\
Melinis repens & Pogonarthria squarrosa & - & - & - \\
Monsonia angustifolia & Solanum sp & - & - & Sesbania bispinosa \\
Ocimum canum & Streptopetalum serattum & - & Sida cordifolia \\
Rhigozum brevispinosum & Tarchonanthus camphoratus* & - & - & Tricholaena monachne \\
Schmidtia pappophoroides & Tricholaena monachne & - & - & - \\
Sesbania bispinosa & Urochloa mosambicensis & - & - & - \\
Sida cordifolia & - & - & - & - \\
Solanum $s p$ & - & - & - & - \\
Streptopetalum serratum & - & - & - & - \\
Urochloa mosambicensis & - & - & - & - \\
\hline
\end{tabular}

*Woody species found within the pits.

Table 3. Plant species common at all three borrow pits.

\begin{tabular}{ll}
\hline Botanical Name & Common Name \\
\hline Acacia tortilis $^{*}$ & Mosu (Hairy umbrella thorn) \\
Acacia gerrardii* $^{*}$ & Moga, Moki (Red thorn; Grey haired acacia) \\
Acacia mellifera* $^{*}$ & Mongana (Black thorn; Hook thorn) \\
Acacia nigrescens* $^{*}$ & Mokoba (Knob thorn) \\
Aristida congesta subsp. barbicollis & Seloka; Bojang-ja-motlhaba-jo-bonnye; (Buffalo grass) \\
Asparagus bechuanicus & Lesitwa, (Wild asparagus) \\
Dicerocaryum eriocarpum & Tshetlho; Legatapitse (Devil's thorn; boot protector plant) \\
Dicoma tomentosa & Ombahu \\
Enchinochloa holubii & (Limpopo grass; Antelope grass; Kalahari water grass) \\
Euclea undulate* & Mothakola (Thicket euclea) \\
Gomphrena celosioides & Mositanoka (Prostate globe amaranthas; bachelor's button) \\
Guilleminea densa & Mohulapitse (Small mat weed) \\
Hypertelis bowkeriana & Motlhabana; Munyu-wa-pasi \\
Kyphocarpa angustifolia & Mosono-wa-mmutla; Silky burweed; Hare's tail bush \\
\hline
\end{tabular}


Table 3. Contd.

\begin{tabular}{ll}
\hline Melinis repens & Lenapa; Senyane (Fairy grass) \\
Monsonia angustifolia & Phusana; Tsatsalopane (Crane bill) \\
Sesbania bispinosa & Mositanokana; Selaole (Spiny sesbina) \\
\hline *Woody species found within the pits. &
\end{tabular}

${ }^{*}$ Woody species found within the pits.

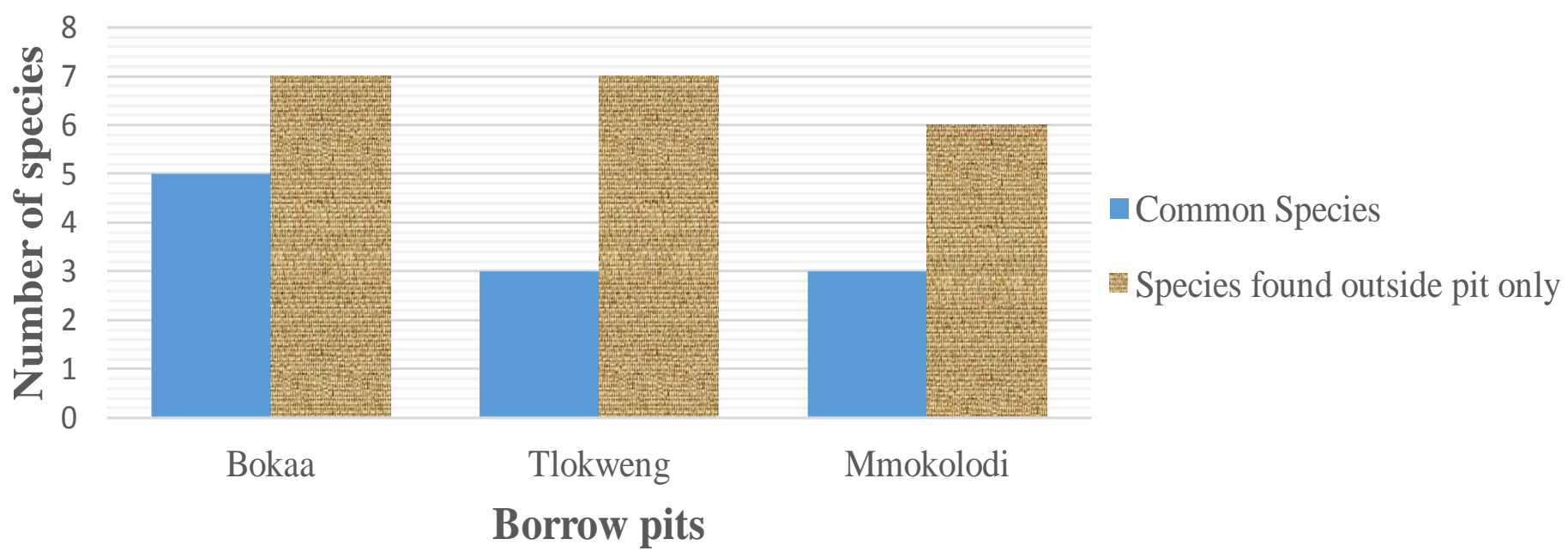

Figure 2. A comparison of woody species within the pits and adjacent to the pits.

from the vegetation stand surrounding the pits. The distance of the different species from the pits and their dispersal characteristics could also have affected what got established in the pits (Makhabu and Marotsi, 2012). It should be noted that vegetation surrounding the pits was only sampled to a distance of $30 \mathrm{~m}$. It was found that the majority of woody species that grew around the pits were not found growing within the pits (Figure 2). With the exception of the Tlokweng pit, majority of non-woody plants that were found around the pits were also found growing inside the pits (Figure 3 ).

\section{Conclusion}

It can be concluded that Acacia species have a great tolerance for poor underdeveloped soils found in decommissioned borrow pits. This can make them suitable candidates for pioneer species in technical reclamation, especially when there is a limitation of topsoil available for revegetation. They can be used to provide conducive environmental conditions for other plant species.

It can also be concluded that most non-woody species are easy to establish in disturbed lands. They are useful in the control of negative impacts such as soil erosion as well as improving the capability for water infiltration. This contributes to the success of other processes such as decomposition which can accelerate development 


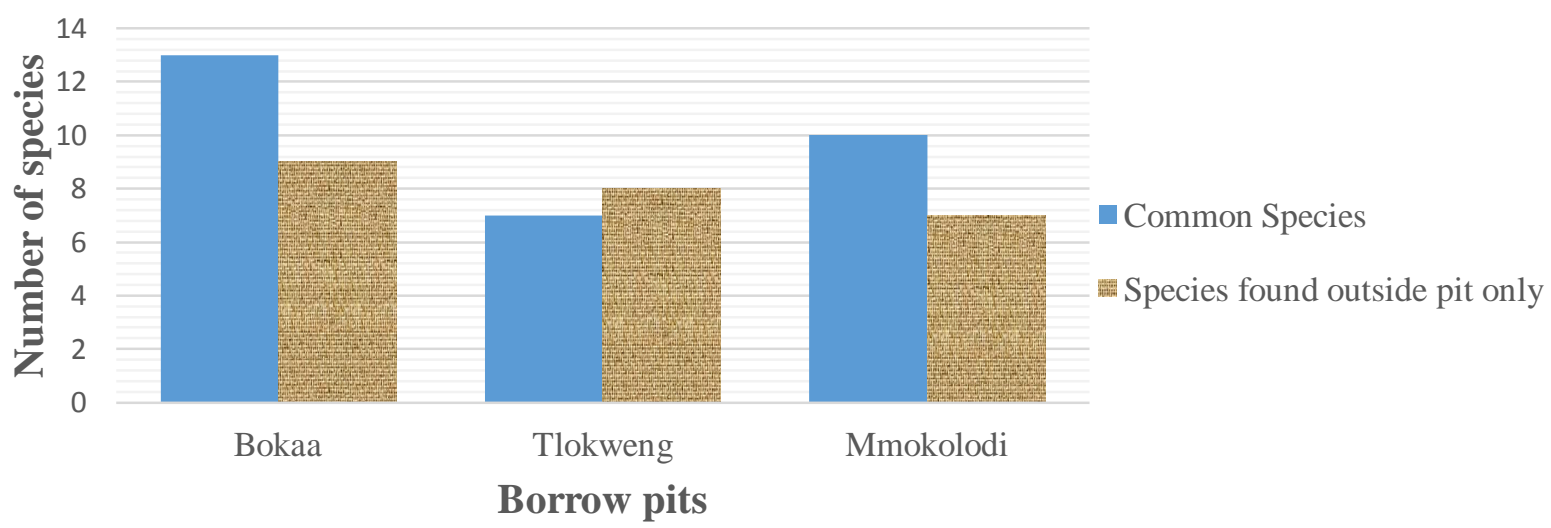

Figure 3. A comparison of non-woody species within the pits and those adjacent to the pits.

\section{of better soil that can support re-vegetation.}

\section{Conflict of interests}

The author(s) did not declare any conflict of interest.

\section{REFERENCES}

Cripps JC, Roubos V, Hughes D, Burton M, Crowther H, Nolan A, Tonks D (2007). Reclamation planning in hard rock quarries: A guide to good practice. Mineral Industry Research Organization (MIRO).

Davis MA, Grime JP, Thompson K (2000). Fluctuating resources in plant communities: a general theory of invisibility. J. Ecol. 88:528534.

Davis BNK, Lakhani KH, Brown MC, Park DG (1995). Early Seral communities in a limestone quarry- an experimental study of treatment effects on cover and richness of vegetation. J. Appl. Ecol. 22:473-490.

Davy AJ (2008). Establishment and manipulation of plant population and communities in terrestrial systems. In: Handbook of ecological restoration, Principles of restoration, Ed. Perrow M.R, Davy, A.J. Cambridge University Press, Cape Town. pp. 223-241.

Donfack PI, Flor H, Pontanie R (1995). Dynamic vegetation around abandoned disturbed land. J. Veg. Sci. 6:499-508

Legwaila I (2012). The effects of quarry treatment and distance on the attractiveness of reclaimed limestone quarry landscapes in England. Ph.D Thesis, University of Sheffield, England.
Makhabu SW, Barotsi B (2012). Changes in herbaceous species composition in absence of disturbance in a CenchrusbiflorusRoxb. Invaded area in Central Kalahari Game Reserve, Botswana. Int. J. Ecol. 2012:6.

Smith TM, Smith RL (2014). Elements of Ecology. Benjamin Cummings, San Francisco, USA.

Vermeulen J, Whitten T (1999). Biodiversity and Cultural Heritage in the Management of Limestone Resources: Lessons from East Asia. Directions in Development Series, The World Bank, Washington D.C.

Whisenant SG (2008). Terrestrial systems. In Handbook of ecological restoration, Principles of restoration, Ed. Perrow M.R, Davy, A.J. Cambridge University Press, Cape Town pp. 83-105. 